J. A. Motyer, Circumcision and Baptism: a reply to Professor Rowlev.
Chm., lxx, pp.25-8.

J. C. Pollock, Editor, Churchman

L. E. PORTER, Review in E.Q.

J. H. STringer, Seventeenth-Century Influences on the Evangelical Revivai, (London Bible College).

The Promise of Sanctification, L.Q.H.R., 1955.

R. V. G. TASker, The Text of the Corpus Paulinum, N.T.S., i, pp. 180-91.

J. G. S. S. Thomson, The Shepherd-Ruler Concept in the O.T. and its application in the N.T., S.J.T., viii, pp. 406-18.

J. A. Thompson, The "Golden Calves" of Jeroboam, Aust. Bib. Rev., iv, pp. 81-4.

D. H. Tongue, The Church of the New Testament, Chm., Ixx.

A. F. Walls, A Primitive Christian Harvest Thanksgiving, Theology, lviii, pp. 336-9.

A. P. Waterson, Miraculous Healing, Chm., lxx, pp. 29-36.

D. J. Wiseman, Chronicles of Chaldaean Kings, (British Museum).

Genesis X: Some Archaeological Considerations, Trans. Vict. Inst., lxxxvii, pp. 13-24.

Secular Records in Confirmation of the Scriptures, Trans. Vict. Inst., lxxxvii, pp. 25-36.

The Excavations at Nimrûd, Brit. Mus. Quart., 1955.

Sub-editor, Iraq.

C. DE WIT, Le Particule demotique hmf, Chr. d'Eg., lix.

Some Values of Ptolemaic Signs, Bulletin de l'Institut francais à Caire. Editor, Chronique d'Égypte.

A. Skevington Wood, Industrial Evangelism, Exp. Times, lxvii, pp 172-4.

J. Stafford Wright, What is Man? (Paternoster Press).

The Interpretation of the Bible, (I.V.F.).

Some Modern Religions, (Tyndale Press).

(With J. O. Sanders.)

\title{
JEREMIAH vii, 22
}

The interpretation of this verse which has been commonly given has made Jeremiah a downright opponent of ritual worship as such, even to the point of denying that it corresponds in any way to the will of God. Some have been content to leave it so, taking the verse as implying that ritual legislation came later than the prophet; others have suggested the expedient that Jeremiah was thinking only of the Decalogue, which contains no ritual prescriptions. Neither of these is satisfactory-the second, if for no other reason than that the Decalogue was promulgated in the setting of Sacrifice. The following note desires to offer a few suggestions which may aid the understanding of the verse.

(1) Negatively, the context makes clear what the words cannot mean, e.g. vv. 9-10 do not condemn the people for coming to stand before Yahweh in the Temple (for the possible ritual significance of the verse here, see, e.g. Lev. ix, 5) because Yahweh disapproves of sacrifice, but because the show of worship was accompanied by a general iniquity of life. Verse 11 calls the Temple "this house which is called by My Name"-an unlikely designation if Yahweh heartily disowned all that was done there! Verse 12 speaks of Shiloh as "My place," and related its destruction not to the practice of sacrifice but to the wickedness of Israel. Jeremiah does not seem to be opposed to sacrificial worship as such-the point could be proved at length in writings. If vii, 22, really evidences an opposition to such worship, then it is an isolated outburst, and we must hold that Jeremiah spoke in haste, and without due consideration.

(2) This expedient is not necessary, for, turning to the positive teaching of the verse, we find it to be capable of a perfectly simple explanation. The preposition translated "concerning" is "al dibhrei. Basically, this' expresses 
the notion of "cause." See BDB dabhar 8: "reason, cause.") . There are, therefore, two broad translations of the preposition: (1) "Because of"looking back to that which gives rise to a certain state of affairs as a cause gives rise to an effect; and (2) "For the sake of"-looking forward to the end at which a certain action aimed, and out of desire for which it was performed. These are the basic translations of the words; they can only mean "concerning" in so far as the proper meanings can shade off into that vaguer meaning. Thus, e.g. in Genesis xx, 11, A.braham could say, "They will slay me concerning my wife," but the words demand "for the sake of" or "because of." In Genesis xliii, 18, Joseph's brothers could merely say that their being brought to the house was "concerning the money," but the situation demands again "because of"-that is what caused their state. In Jeremiah xiv, 1, we find the translation "concerning the drought" and yet it is clear that the drought is not the subject of the oracle but its cause. Again the text needs to be translated, "Because of." To return to the verse under discussion: Jeremiah is not at all stating that Yahweh had nothing to say "about" sacrifice, but that His words were neither "because of" nor "for the sake of" sacrifice: He made a Covenant with Israel neither "because" she offered Him sacrifice, nor yet "for the sake of" any sacrifice she might offer. The "cause" of the Covenant was, on the one hand, Divine Grace, and on the other Israel's acceptance of the moral requirements of her Redeemer; therefore (Ex. xxiv, 8) the Covenant is said to be ratified "on the basis of all these words," and consequently Jeremiah is correct to stress (v. 23) the command which God gave at Sinai. But Israel stood in constant need of forgiveness and restoration. She had committed herself to a standard from which she was constantly falling. In the setting of Yahweh's ethical requirement and Israel's ethical response the sacrificial system has its permanent place, which was not denied by Jeremiah.

\section{Clifton Theological College, \\ Bristol 9 \\ THE PENETRATION OF GRAECO-ROMAN SOCIETY BY CHRISTIANITY}

J. A. MOTYER.

With all our modern statistical equipment it is difficult enough to say how widely held the Christian faith is, or from what social groups its strength is mainly drawn. For the ancient world there are not even any statistics. A few census returns supply the numbers of certain sections of the population at odd times, but leave untouched women, children, foreigners, or others without civil rights. Many attempts have been made to fill the gaps by calculating from grain consumption, built-up areas, rate of burials, and so on, but the very diversity of method shows how uncertain the results are. Even if we could draw a cross-section of ancient society, we should still have trouble fitting the Church membership in. Christians may have been well enough known in their own community, but usually they either felt no need or thought it unwise to leave any lasting public record of their faith. The first overtly Christian tombs that we know were set up in public are in the isolated uplands of central Anatolia. They come from the third century, and could be a cry of defiance from a Church that held passionately to the duty of open confession in troubled times. "So and so to his sweetest wife so and so, in remembrance, one Christian to another." They give us an intimate glimpse into the relations between one group of Christians and its neighbours, but their brief light only heightens the darkness around. Quite a plausible general picture of the numbers and standing of the members of the Church can be built up from the incidental information given by New Testament and patristic writers, but such impressions could be misleading if not subject to detailed testing.

There are, of course, plenty of ancient writers who comment expressly on the subject, but they are often more anxious to persuade than to inform. To the apostles, for instance, the universal preaching of the Gospel was not a question of fact so much as an article of faith. It was the precondition of the end. The more imminent they conceived the end to be, then, the more readily did they anticipate the completion of their mission. The 